\title{
Legal ecological zoning with estimation of complexity of the landscape organization of the protected zones of Russkiy Island
}

\author{
Ruslan Borisov ${ }^{1}$, and Kirill Ganzei ${ }^{1, *}$ \\ ${ }^{1}$ Pacific Geographical Institute of the Far Eastern Branch of the Russian Academy of Sciences, Radio, \\ 7, 690041, Vladivostok, Russia
}

\begin{abstract}
We have carried out legal ecological zoning of Russkiy Island. The categories of protected lands have been defined on the island in agreement with a normative legal base. Data processing of remote sensing, the digital models of a relief, and the data of the state registers has allowed us to calculate the areas of protected lands and to obtain a cartographical image of legal ecological zoning of Russkiy Island. Using quantity indicators, data processing of the landscape organization has allowed us to analyze the features of a spatial structure of landscapes, landscape complexity, and a landscape variety of the protected zones of Russkiy Island. For comparison the analysis of the landscapes of the unprotected territory was carried out too. The analysis of complexity of a landscape drawing and a landscape variety implemented in the present work defines the territory of the protected lands as the most difficult and non-uniform one by the landscape organization compared with the unprotected territory of the island. The estimation of the landscape organization of the protected zones of Russkiy Island is an important component part of the further studies directed to the formation of the balanced system of control by the island nature-economic system.
\end{abstract}

\section{Introduction}

Russkiy Island is located in the Peter the Great Bay of the Sea of Japan and part of Vladivostok city district. The island is $99.7 \mathrm{~km}^{2}$, making it the largest island in the gulf. Russkiy Island is located closer to the city of Vladivostok than other islands. Given this connection, special attention is drawn to its development both on the regional and federal levels. For instance, hotels and conference centers were constructed on the island in preparation for the Asia-Pacific Economic Cooperation (APEC) summit in 2012. This infrastructure is now being used as a campus of the Far Eastern Federal University. A bridge now connects Russkiy Island with the main part of the city and further infrastructure development has promoted integration of the island into the social-economic network of Vladivostok. According to the Vladivostok urban district general plan, further construction is planned on the island, which could radical transform the islands natural environment. Given these circumstances, sustainable development is the question of the day.

In May 2017 the Concept of development of Russkiy Island up to 2027 [1] was accepted by the Government of the Russian Federation. The plan includes creating a

\footnotetext{
* Corresponding author: geo2005.84@ mail.ru
} 
territory of advanced social-economic development (TORs) that utilizes private-state partnership as a basic variant of development. According to this concept, priority would be given to educational, scientific, cultural, tourist-recreational, and exhibition development. All of the current proposals and concepts of development on Russkiy Island consider it only as "a territorial resource" - a portion of land, on which it is possible to erect economic infrastructure. However, the presence of landscape resources are not taken into consideration. Sustainable use of these landscape resources should form a basis for a system of nature use that provides for all nature users.

Development of Russkiy Island should be guided by comprehensive assessment of the island's landscape resources including large-scale thematic mapping and landscape planning. Anthropogenic transformation of geosystems can negatively influence not only landscape sustainability, but also preservation of social - economic potential. Preservations of the island's natural environment has been observed despite active economic development and increasing anthropogenic pressure on the island during the last 150 years, including infrastructure projects in 2008-2012 [2]. Preservation of the natural environment must be incorporated into plans of future development of Russkiy Island.

It is possible to regulate land and resource use based on legal ecological zoning that ensures regulatory protection of nature and provides long-term forecasts of regional development. Legal ecological zoning is based on division of the territory into specific zones. Each zone then has land-use restrictions that are detailed in normative legislative documents and take into account features of the territory [3].

Accurate fixation of the norms of economic use of the protected areas registered in the normative legal documents is an important stage of the perspective planning directed at sustainable development of the territory. Analysis of landscape organization and geosystem function is also an important stage when planning regional development.

\section{Purpose and methods}

This study focuses on legal ecological zoning of Russkiy Island defined by the normative legal documents operating in Russia, as compiled using geospatial modeling and quantitative analysis of landscape organization of protected zones. In agreement with a set purpose, the complex of problems has been carried out: the features of the landscape organization of the island were considered; the categories of protected lands were defined according to legislation of the Russian Federation; remote sensing data, digital models of the relief, and the data of Russia's governmental registers were processed; mapping of the protected lands were implemented; the landscape structure of the protected zones were analyzed; calculation of indicators of complexity of a landscape structure and a landscape variety of protected zones of Russkiy Island was conducted.

We used qualitative and quantitative methods, relying particularly on cartographical and geostatistical approaches. The normative legal base of the protected lands of the Russian Federation [4-6] were analyzed. Remote sensing data were presented using GoogleEarth, and the data on the landscape organization [7] were processed using the software package ArcGIS10.3. Quantitative analyses of landscape structure and variety were carried out for protected lands of Russkiy Island. This work used groups of elementary indicators and indicators of complexity of a landscape drawing (tab. 1 [8]).

\section{Results and discussion}

The Far Eastern boreal and subboreal middle - and south taiga of pacific landscapes with the characteristic monsoonal circulation of air masses are present on Russkiy Island [9]. 
The employees of the Pacific Institute of Geography of the Far Eastern Branch of the Russian Academy of Sciences have carried out studies on landscape organization [10] and mapping of [7] the islands. The entire territory of the island refers to a mountain class of landscapes. The functional features of an islands closed geosystem manifest at the level of landscapes subclasses. Over 81 percent of the territory of the island fallsina low mountain subclass that is mainly generated by denuded slopes of moderate steepness. Under monsoonal climate conditions with precipitation exceeding $800 \mathrm{~mm} / \mathrm{year}$, the landscapes are characterized by high humidity. The island landscapes are subdivided into the following groups: automorphic, hydromorphic, and semihydromorphic.Moderately-slopedlandscapes composed of granites and granitoids support broad-leaved maple-ash-alder-lime forest communities that have brushwood-tall herbs and dominated by lianas on burozems [10].

Table 1. Quantitative methods for analyzing landscape maps [8].

\begin{tabular}{|c|c|c|}
\hline$\#$ & Type of indicator & Designation/formula \\
\hline \multicolumn{3}{|c|}{ A group of the elementary characteristics } \\
\hline 1. & The area of the region (zones) & $\mathrm{S}$ \\
\hline 2. & $\begin{array}{c}\text { The area of one species of the landscape on } \\
\text { the island }\end{array}$ & $\mathrm{Si}$ \\
\hline 3. & Quantity of landscape species & $\mathrm{m}$ \\
\hline 4. & Quantity of contours & $\mathrm{n}$ \\
\hline 5. & $\begin{array}{l}\text { Average quantity on } 1 \text { nature-territorial } \\
\text { complex }\end{array}$ & $\mathrm{p}$ \\
\hline 6. & Average area of landscape contours & $S_{0}=\frac{S}{n}$ \\
\hline \multicolumn{3}{|c|}{ A group of complexity characteristics } \\
\hline 7. & Fractional index of landscape contours & $k=\frac{n}{S}$ \\
\hline 8. & The degree of difficulty & $K=\frac{n}{S_{0}}$ \\
\hline 9. & $\begin{array}{l}\text { Entropy measure of complexity of a } \\
\text { landscape drawing }\end{array}$ & $H=-\sum_{i=1}^{m} \frac{s_{i}}{s} \log _{2} \frac{s_{i}}{s}$ \\
\hline 10. & The Margalef index & $D_{m g}=\frac{(M-1)}{\ln _{S}}$ \\
\hline
\end{tabular}

According to the normative legal base of the Russian Federation, on Russkiy Island three categories of protected lands are defined: a water protected zone (except for the water area of the water objects taken for a basis), natural protected areas (NPAs), and areas with objects of cultural or historical significance. In these territories, any activity that disturbs the integrity of cultural or historical objects is forbidden by law [4-6].

Analysis of the water protected zone allowed us to single out watercourses, the largest of which is the Russkaya River that extends approximately five kilometers. The Russkaya River is the largest island river in Primorskii Krai. It originates in the southern slopes of Russkaya Mountains, flows south and southwest, and then enters Melkovodnaya Bay. Other watercourses on the island are considerably smaller. We have singled out14 lakes, that total $0.14 \mathrm{~km}^{2}$. On the basis of Federal law 03.06.2006 N 74-FZ [4] «the Water Code of the Russian Federation» the width of the buffer zone of each watercourse and lake is $50 \mathrm{~m}$, and the width of the water protected zone in the sea is $500 \mathrm{~m}$. Based on these specifications, 
we calculated the area of the water protected zone of Russkiy Island to be 5,350.48 hectares (53.7\% of the territory of the island).

On the Russkiy Island NPAs there are three regional landmarks with a total area of 4.65 hectares $(0.1 \%$ of the territory of Russkiy Island). The largest section, Tobizinsky, represents a strato-typical exposure of Low Trias rocks, located along the coast of the island between the Karamzin and Pologaya Capes . Another section, Aniziisky, is located along the coast between Karamzin Cape and Chernyshev Bay. It is characterized by exposed rocks from the Anisianstage of the middle Triassic, that are composed of thick aleurolites with interlayers of sandstones containing a rich complex of bivalve mollusks. The Chernyshevsky geological section is located on the coast of Chernyshev Bay and is composed of exposed rocks from the Low Triassic that have thick aleurolites with high lime concentration. These formations also contain a rich complex of bivalve mollusks and ammonites of the Olenekian stage of Low Trias [11].

Analysis of objects with cultural-historical significance allowed us to single out Vladivostok's fortress. Vladivostok's fortress is a unique long-term defensive complex. This fortress was constructed between the end of the 19th and early 20th centuries in the modern Vladivostok urban district. This history includes use during the Russian-Japanese war (1904-1905). The fortress appears to be the most defended compared to other regional fortresses, which have been constructed and reconstructed [12]. There are 6 forts, 25 batteries, 13 caponiers, and 3 cellarson Russkiy Island. These details are provided by «Landmark's passport of the object of cultural heritage of the federal meaning «the Complex of fortification constructions of Vladivostok's fortress, 1889-1914, engineers Velichko K.I., Shoshin A.P., Chernoknizhnikov K.S., and others» [13], and also by the data of the Uniform governmental register of the objects of cultural heritage (history and culture monuments) of the people of the Russian Federation [14]. The area with objects of culturalhistorical significance is 196.01 hectares ( $2 \%$ of the island). This estimate was derived by mapping city-building zones from the city-building portal of the Vladivostok administration. [15]. Archeological monuments are also considered to be objects of cultural-historical significance. Archeological monuments are widely present on the islands according to the Institute of History, Archeology and Ethnography of the People of the Far East of the Far Eastern Branch of the Russian Academy of Sciences; however, these monuments are neither included in governmental accounting and or register.

Thus, the largest area of protected lands is occupied by the water protected zone, which totals 5,350.48 hectares (53.7\% of the island). The lands with objects of cultural-historical significance occupy 196.01 ha (2\% of the island territory). The smallest areas occupy NPA lands -4.65 hectares $(0.1 \%$ of the island territory). Figure shows legal ecological zoning in the central part of Russkiy Island.

Analysis of remote sensing data and landscape organization data allowed us to assess landscape organization of the protected zones of Russkiy Island. This analysis did not include anthropogenically transformed areas to which the lands of the objects of culturalhistorical heritage are referred. NPAs represent less than $0.1 \%$ of the island and are located along a coastline. There fore, their lands are considered part of the water protected zone of the sea. We analyzed spatial features of the water protected zones including lakes, water currents, and the sea based on indicators of complexity of a landscape drawing and a landscape variety. For comparative purposes, we also analyzed landscapes of an unprotected territory.

The first stage involved calculating elementary indicators of the landscape structure for the investigated territories. These data served as the basis for analysis of landscape complexity and variety (tab. 2). 


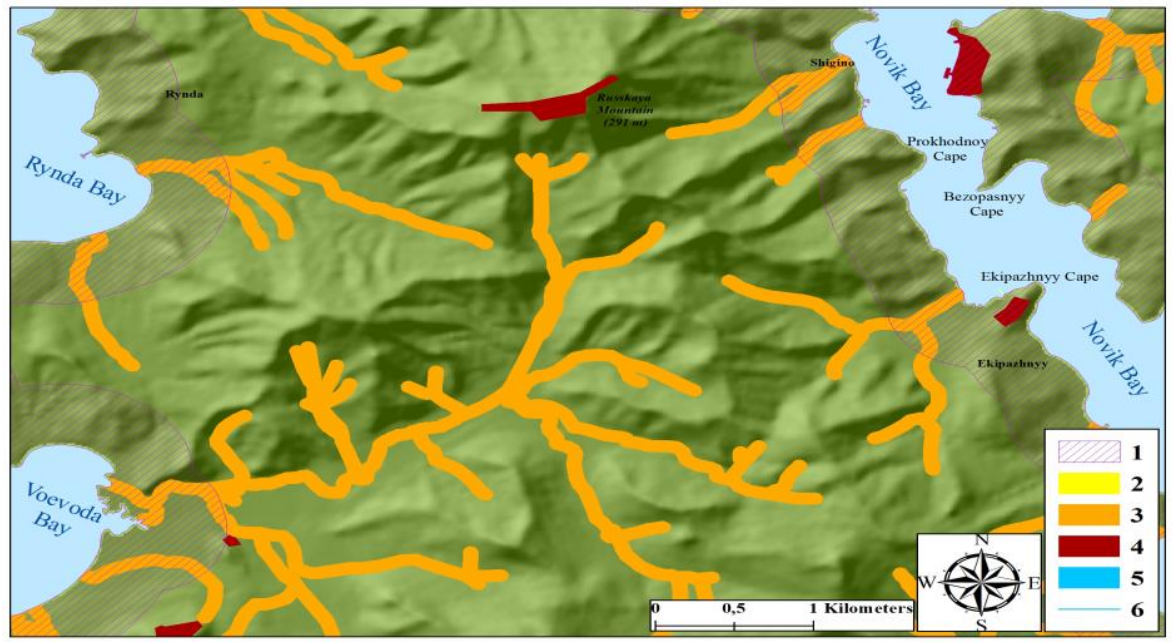

Fig. 1. Legal ecological zoning in the central part of Russkiy Island. Legend: 1 - water protected zone of the sea; 2 - water protected zone of lakes; 3 - water protected zone of watercourses; 4 - objects with cultural-historical significance; 5 - lakes; 6 - watercourses.

The protected zones of Russkiy Island are characterized by higher complexity of landscape drawing (504.72), almost five times greater than the unprotected territory (116.24). The maximum index of the given indicator occurs in the water protected zone of watercourses(823.49); a minimum one fallson the water protected zone of lakes (less than 62.3). The water protected zone of the lakes differs in smaller area, which are characterized by uniformity of landscape structure.

The indicator of entropy complexity of the landscape drawing reflects the probability of change of one landscape to another and is highest for protected zones (9.16). The maximum values occur in the water protected zones of the sea (8.78) and watercourses(8.69). The water protected zone of the lakes have the lowest indicator (4.53).

We estimated the natural variety of protected zones using the R. Margalef technique [16]. In this work, landscape variety is defined the number of the types of landscape and how often they are encountered in a certain territory. Calculating the R. Margalef index made it possible to define the degree of landscape variety for protected zones and the unprotected territory. The protected zones have a higher R. Margalef index(25.8) in comparison with the unprotected territory (15.89). The maximum value of this indicator occurs in the water protected zone of the sea (24.46); whereas the minimum occurs in the water protected zone of lakes (7.59).

\section{Conclusions}

Protected zones have been created for the purpose of preserving he natural function of the territory. Our analysis testifies to the fact that protected zones of Russkiy Island have high complexity and landscape variability. Out of 236 types of the landscapes on the island, 218 types occur in the protected territory. The water protected zones of the sea and water courses differ in landscape complexity and variety with 203 and 131 types of landscapes, respectively. Protected watercourses zones play an important role in the functioning of geosystems. Representing vector natural systems, watercourses play a key role in a substance-power interactions between natural complexes in landscape catene. Based on these data, it is evident that water protected zone of the sea are important aspects of island natural systems. 
Table 2. Quantitative indicators of landscape structure for protected zones on Russkiy Island.

\begin{tabular}{|c|c|c|c|c|c|}
\hline \multirow[b]{2}{*}{ Zone } & \multicolumn{5}{|c|}{ Simple characteristics } \\
\hline & Area, $\mathrm{m}^{2}(\mathrm{~S})$ & $\begin{array}{l}\text { Number of } \\
\text { contours (n) }\end{array}$ & $\begin{array}{l}\text { Number of } \\
\text { the types of } \\
\text { landscapes } \\
\text { (m) }\end{array}$ & $\begin{array}{c}\text { Average } \\
\text { number of } \\
\text { contours per } \\
1 \text { type of the } \\
\text { landscape }(\mathrm{p})\end{array}$ & $\begin{array}{c}\text { Average area of } \\
\text { landscape } \\
\text { contours }\left(\mathrm{S}_{0}\right)\end{array}$ \\
\hline $\begin{array}{c}\text { Protected } \\
\text { zones of }\end{array}$ & 4493.62 & 1506 & 218 & 6.91 & 2.98 \\
\hline lakes & 26.98 & 41 & 26 & 1.58 & 0.66 \\
\hline watercourses & 955.41 & 887 & 131 & 6.77 & 1.08 \\
\hline the sea & 3861.94 & 1077 & 203 & 5.31 & 3.59 \\
\hline $\begin{array}{c}\text { Unprotected } \\
\text { zone }\end{array}$ & 4312.43 & 708 & 134 & 5.28 & 6.09 \\
\hline \multirow[b]{2}{*}{ Zone } & \multicolumn{5}{|c|}{ Complexity characteristics } \\
\hline & $\begin{array}{l}\text { Fractional } \\
\text { index of } \\
\text { landscape (k) }\end{array}$ & $\begin{array}{l}\text { Degree of } \\
\text { difficulties of } \\
\text { a landscape } \\
\text { drawing }(\mathrm{K})\end{array}$ & $\begin{array}{c}\text { Entropy } \\
\text { measure of } \\
\text { complexity a } \\
\text { landscape } \\
\text { drawing }(\mathrm{H}) \\
\end{array}$ & \multicolumn{2}{|c|}{ The Margalef index (Dmg) } \\
\hline $\begin{array}{c}\text { Protected } \\
\text { zones of }\end{array}$ & 0.34 & 504.72 & 9.16 & \multicolumn{2}{|c|}{25.80} \\
\hline lakes & 1.52 & 62.30 & 4.53 & \multicolumn{2}{|c|}{7.59} \\
\hline watercourses & 0.93 & 823.49 & 8.69 & \multicolumn{2}{|c|}{18.94} \\
\hline the sea & 0.28 & 300.35 & 8.78 & \multicolumn{2}{|c|}{24.46} \\
\hline $\begin{array}{c}\text { Unprotected } \\
\text { zone }\end{array}$ & 0.16 & 116.24 & 6.45 & \multicolumn{2}{|c|}{15.89} \\
\hline
\end{tabular}

The ecological zoning of Russkiy Island carried out in this work included analysis of landscape complexity and variability. The analysis showed that protected zones are more complex and non-uniform in comparison with an unprotected territory despite small differences between areas. Characterizing landscape organization in protected zones is crucial for balanced management of the island's nature -economic system and for realization of the principles of sustainable development in the territory.

This research was funded by the Russian Science Foundation - project 18-77-00001.

\section{References}

1. Government of the Russian Federation. Order of May 30, 2017 No. 1134-r. Available at:http://static.government.ru/media/files/HYZCbj816A7jC4UErg2A6Dt2aVufpxJN.pd $\mathrm{f}$ (accessed: 11.02.2020)

2. K. Ganzei, Geography and Natural Resources, 3, 160-167 (2016) doi: 10.21782/GiPR0206-1619-2016-3(160-167)

3. S. Lesnykh, Service and Tourism: current challenges, 3, 22-30 (2018) doi: 10.24411/1995-0411-2018-10302

4. Water Code of the Russian Federation of June, 3, $2006 \mathrm{~N}$ 74-FZ https://rg.ru/2006/06/08/voda-kodeks.html (accessed: 11.02.2020)

5. Federal Law "On Specially Protected Natural Areas" dated March 14, 1995 N 33-FZ (last revised) http://www.consultant.ru/document/cons_doc_LAW_6072 (accessed: 11.02.2020) 
6. Federal Law "On Cultural Heritage Objects (Historical and Cultural Monuments) of the Peoples of the Russian Federation" dated June 25, 2002 No. 73-FZ (last revised) http://www.consultant.ru/document/cons_doc_LAW_37318 (accessed: 11.02.2020)

7. K. Ganzei, A. Kiseoleva, N. Pshenichnikova, Landscapes of Russkiy Island. Map. Scale 1:25000 (LLC "Kolorit", 2016)

8. A. Viktorov, Risunok landshafta (Mysl', 1986)

9. A. Isachenko, Landshafty SSSR (Izdatelystvo Leningradskogo universiteta, 1985)

10. K. Ganzei, A. Kiseoleva, N. Pshenichnikova, Advances in current natural sciences, 6, 138-143 (2016)

11. Information and analytical system "Specially Protected Natural Areas of Russia" http://oopt.aari.ru (accessed: 11.02.2020)

12. Vladivostok KFSS Team, Vladivostok fortress http://kfss.ru/object/obektyvladivostokskoy-kreposti/vladivostokskaya-krepost (accessed: 11.02.2020)

13. Interactive map of the Vladivostok fortress http://fortvl.ru (accessed: 11.02.2020)

14. Ministry of Culture of Russia, Information from the Unified State Register of Cultural Heritage Objects (Historical and Cultural Monuments) of the Peoples of the Russian

Federation https://opendata.mkrf.ru/opendata/7705851331-egrkn (accessed: 11.02.2020)

15. Geoinformation portal of the city administration of Vladivostok http://maps.vlc.ru (accessed: 11.02.2020)

16. R. Margalef, Oblik biosfery (Nauka, 1992) 